\title{
Implementation of Indonesian National Qualification Framework (INQF) for Accounting Diploma
}

Surya Jatmika

Accounting Education Department

Universitas Muhammadiyah Surakarta

Surakarta, Indonesia

surya.jatmika@ums.ac.id

\author{
Nahiyah Jaidi Faraz \\ Management Department \\ Universitas Negeri Yogyakarta \\ Yogyakarta, Indonesia \\ nahiyah@uny.ac.id
}

\begin{abstract}
Since 2012, Indonesian Government has implemented Indonesian National Qualification Framework (INQF) on higher education to face global competition era. Although INQF has been applied since 2012, the Accounting Diploma Program of Universitas Negeri Yogyakarta is implementing a curriculum that has been adjusted to INQF in 2015. This study aims to describe the process of drafting and obtain information about the relevance of the curriculum for Accounting Diploma Program to the 5th Level of INQF. This study was qualitative research. The research object was the curriculum of Accounting Diploma Program in Universitas Negeri Yogyakarta (UNY). The research subjects were 19 university lecturers. The data were analyzed using the qualitative data analysis and percentage descriptive statistics. Data collection methods used are interviews, documentation, and questionnaires. The results are (1) Generally, the process of drafting the curriculum of Accounting Diploma Program of Faculty of Economics (FE) UNY is not accordance with the guidelines given from Directorate General of Higher Education. There are some inhibiting factors and supporting factors of drafting the curriculum. The inhibiting factors are the various extra subjects from university and faculty, the insufficient time management in curriculum development, the missing revised file, the difficulty in the preparation of graduates learning outcomes particularly those which contain character values, the complexity in the assessment of each competency, and the lack of library and laboratory facilities. The supporting factors are the policy and guidance established by university and faculty management to support the implementation of INQF, the recognition of Head of Accounting Diploma Program of FE UNY on the required curriculum adjustment to the needs of graduate users, and the availability of the guideline of INQF-based curriculum development published by the Directorate General of Higher Education. (2) The level of the relevance for the courses of Accounting Diploma to the 5 th Level of INQF is $54.29 \%$.
\end{abstract}

Keywords-the process of drafting, curriculum, accounting diploma, the 5th Level of INQF

\section{INTRODUCTION}

Globalization has brought a seemingly endless process of change within education, in which many countries have applied similar curriculums that accommodate the global need requirement (Priestley, 2002) ${ }^{1}$. The current educational curriculum is mostly ubiquitously developed nationally and internationally by the national and local curriculum committees. Moreover, curriculum that contains knowledge and study of the world (e.g., world history, world geography, and world affairs) has been developed by the state (Parker, Ninomiya, \& Cogan, 1999) ${ }^{2}$.

The development of an educational curriculum that accommodates the global needs has stimulated the improvement of a national qualification framework for a country as a means of facing the era of global competition. This qualification framework aims to improve the quality of higher education and training through the recognition of accreditation qualifications proposed by diverse agencies (Wijeyaratne, 2012) ${ }^{3}$.

In 2012, the Government of the Republic of Indonesia issued a policy on the implementation of the Indonesian National Qualifications Framework/ INQF (Kerangka Kualifikasi Nasional Indonesia/KKNI) to improve the quality of professional and human resources of Indonesia. The implementation of INQF refers to the Presidential Regulation No. 8 of 2012 (Presiden RI, 2012) (n) $^{4}$ on the Indonesian National Qualifications Framework. It is a framework of job qualification that juxtaposes, equalizes, and integrates the education and training sectors and the work experiences in the context of providing the recognition of skills and job positions in various sectors. Indonesian National Qualification Framework/INQF consists of 9 (nine) levels of qualification, ranging from basic (level 1) as the lowest to advanced (level 9) as the highest level.

The implementation of INQF in Indonesia is activated by the external and internal factors. External factors are related to the global challenges and 
competition that are linked to the Indonesia's incorporation on the ratification of various international conventions and agreements. Nevertheless, the human competitiveness of Indonesia is relatively low. Based on the Human Development Report, Indonesia ranked $113^{\text {th }}$ of 188 countries in 2016, which was lower from the rank of $110^{\text {th }}$ in 2014 (UNDP, 2016) ${ }^{5}$. Meanwhile, Indonesia ranks in the $90^{\text {th }}$ position for the Asia-Pacific countries included in the Global Talent Competitiveness Index (GTCI) 2015-2017, but it tends to be stagnant (Lanvin \& Evans, 2016; Lanvin $\&$ Evans, 2017) ${ }^{6,7}$. Furthermore, internal factors are associated with the inequality in quality, number, and ability of graduates from educational institutions in Indonesia.

High quality education is a necessity, in which the endeavors to improve the quality of education is nonnegotiable issues (Soenarto, Kartowagiran, \& Jaedun, 2013, p. 1$)^{8}$. Previous studies on higher education disclosed the obstructions endured by several study programs, which indicated the lack of quality assurance from Higher Education (Sambada \& Zuchdi, 2002; Lukitawati, 2004; Latifah, 2012;

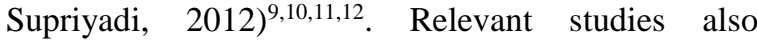
reinforced the obstacle faced by each Study Program in Higher Education, both the State Universities and Private Universities, regarding with the curriculum implementation.

Accounting Diploma Program, Faculty of Economics (FE) is one of the study programs offered by Universitas Negeri Yogyakarta (UNY). FE UNY is the youngest faculty in UNY, in which it was formerly incorporated in the Faculty of Social and Economic Sciences (FISE) UNY. In 2011, the Faculty of Economics was officially established. Moreover, the diploma program of this faculty aims to produce graduates eligible for the title of Intermediate Experts who can work directly in the business and industrial realm. Accounting Diploma Program is under the auspices of the Accounting Education Department. This department consists of Accounting Education Study Program (S1), Accounting Study Program (S1), and Accounting Diploma Program (D3).

The success of the Accounting Diploma Program of FE UNY in generating graduates with high competitiveness in the world of employment is closely related to the applied curriculum. The applied curriculum shall be able to accommodate the competencies and the development of science and technology in demand. One of the main issues is the alignment of INQF in the curriculum of Accounting Diploma Program - which is classified into the $5^{\text {th }}$ level of INQF. Despite of the INQF has been implemented since 2012, the Accounting Diploma Program of FE UNY initially implemented a curriculum that has been adapted to INQF in 2015.
Nevertheless, based on the investigation on the website of Institut Pertanian Bogor as one of the prominent universities in Indonesia, the Accounting Diploma Program of this university has published a INQF-based curriculum in 2012 (IPB, 2012) ${ }^{13}$. Therefore, it is presumed that there might be obstacles in the development of INQF-based curriculum for Accounting Diploma Program of FE UNY, which are important to be revealed and discussed. The faster the alignment of the curriculum of Accounting Diploma Program to the $5^{\text {th }}$ level of INQF, the higher quality and competitiveness of the graduates of Accounting Diploma Program in Indonesia as well as in free labor market of ASEAN.

After the issuance of Presidential Regulation No. 8 of 2012 and the Regulation of the Minister of Education and Culture No. 73 of 2013, the Indonesian Institute of Accountants (Ikatan Akuntan Indonesia/IAI) with Budhi Purwantoro Jati as the representative in the National Accounting Symposium of IAI-KAPD (the Indonesian Institute of Accountants-Compartment of Accounting Educators) in Manado, issued the guideline for reconstruction of curriculum of Accounting Diploma Program based on the $5^{\text {th }}$ level of INQF (Jati, 2013) ${ }^{14}$. This guideline covers the descriptors of the $5^{\text {th }}$ level INQF, learning outcomes of Accounting Diploma Program, learning of the graduates of Accounting Diploma Program, and standard curriculum (subjects) of Accounting Diploma Program, which have provided a comprehensive guidance and reference for each Accounting Diploma Study Program in Indonesia in preparing a new curriculum and implementing it into the learning process immediately. The rapid and accurate implementation of new curriculum is expected to further enhance the competitiveness of the graduates of Accounting Diploma Program. The competitiveness of good graduates and the assurance of suitability of graduate competence with INQF standards of IAI profession will provide opportunities for better career opportunities in the business and industrial world, both at the national and multinational level.

In 2013, the Accounting Diploma Program of FE UNY received $B$ accreditation from the National Accreditation Agency for Higher Education (Badan Akreditasi Nasional Perguruan Tinggi/BAN-PT). Furthermore, the assessor team recommended several points, namely: (1) Lecturer competence development, the competence requirement of accounting is dynamic and rapidly growing as well as lecture materials that must be up to date, (2) Update of accounting books collections in the library, (3) Open access information for students, students learn anywhere instead of restricted in the class, therefore access to information is crucial for student's independent learning, (4) Academic climate development by creating a planned and scheduled academic atmosphere and collective commitment, 
and (5) Self-evaluation should be designed annually (Isti, 2013 $)^{15}$. The recommendations generated from the accreditation visitation indicate the numbers of required improvement in the implementation of teaching and learning activities in Accounting Diploma Program of FE UNY. Quality of teaching and learning activities of a study program will obviously affect the quality of the graduates and the achievement of learning mastered by the graduates.

This study was conducted due to the propensity of inaptness between the 2014 INQF-based curriculum of Accounting Diploma Program of FE UNY and the curriculum of Accounting Diploma Program of IAIKAPD version. Based on the initial document analysis conducted by the researchers, there are some incongruities, among others on the learning outcomes of the study program, the graduate learning outcomes, and list of subjects between the two institutions. Therefore, a thorough study on the relevance level of the INQF-based curriculum devised by Accounting Diploma Program of FE UNY and the curriculum produced by IAI-KAPD is required. The $5^{\text {th }}$ level of INQF issued by the Directorate General of Higher Education and the Indonesian Institute of Accountants (IAI) is a solution in overcoming the incompatibility of graduate competence with the demand of the working world, both nationally and globally. It is expected as the main reference in equalizing the quality of graduates from the Diploma Program (including Accounting Diploma Program) throughout Indonesia.

Previous studies especially on Accounting Diploma Program of FE UNY were mostly focused on curriculum implemented by the Diploma Program with career needs from the users of the graduates and the alumni's point of view of this study program. Study that carried out the alignment of the curriculum of Accounting Diploma Program to the $5^{\text {th }}$ level of INQF learning outcomes of Accounting Diploma Program of FE UNY, learning outcomes of the study program, and looking through the standard curriculum (subjects) of Accounting Diploma Program of FE UNY from various points of view of the association or lecturers outside of Accounting Diploma Program of FE UNY were never been implemented by other researchers before. Therefore, viewing from these significances, the authors chose to focus on that title.

\section{RESEARCH METHODOLOGY}

\section{A. Research Type}

This study is descriptive research with qualitative approach equipped with quantitative data (percentage). The qualitative approach was selected since it is a case study. Quantitative data in the form of percentage analysis derived from the responses of questionnaire, which were used to determine the percentage of relevance between the program curriculum (the $5^{\text {th }}$ level of INQF) issued by IAIKAPD in 2013 and the implementation of the prevailing curriculum of Accounting Diploma Program of FE UNY.

\section{B. Research Time and Location}

The study was conducted in the campus of Diploma III UNY Wates, Kulonprogo, Yogyakarta Special Province, Indonesia which was performed in April to May 2016.

\section{Research Subject and Object}

Subjects or respondents of this study were 19 lecturers of Higher Education Institutions. Specifically, they consisted of three lecturers of Accounting Diploma Program of FE UNY as the respondents in the interview. In addition, the questionnaires were distributed to 5 lecturers of Accounting Diploma Program of Akademi Akuntansi Yayasan Keluarga Pahlawan Negara (AA YKPN), six lecturers of Accounting Diploma Program of Universitas Gadjah Mada (UGM), and five lecturers of Accounting Diploma Program of Universitas Islam Indonesia (UII). The subject for documentation was the 2014 Curriculum of Accounting Diploma Program of FE UNY. The object of this study was the curriculum of Accounting Diploma Program of FE UNY and the $5^{\text {th }}$ level of INQF.

\section{Data Collection Technique}

Data collection techniques included: (1) Interview. This method was used to obtain data about the process of preparation and alignment of the curriculum of Accounting Diploma Program of FE UNY with the $5^{\text {th }}$ level of INQF through interviews with three lecturers of the program. There were three lecturers of Accounting Diploma Program of FE UNY (Head of the Study Program, Vice-Dean I of Diploma Program of FE UNY, lecturer of Accounting Diploma Program of FE UNY). In addition, interview method was used to gain information about the inhibiting and supporting factors in the process of the curriculum development. This method was developed based on INQF-based curriculum established by Directorate General of Higher Education (Ditjen Dikti), (2) Documentation. This method was used to collect data on the process of the curriculum development based on the $5^{\text {th }}$ level of INQF. Documentation covered the list of courses and the prevailing curriculum, documents of study program learning outcomes, and documents of graduates learning outcomes, (3) Questionnaire The authors were intended to use Focus Group Discussion (FGD) to gather lecturers from three universities. However, because of financial matter and lack of time selection to gather the lecturers, the authors chose to use questionnaire. This method was used to obtain data about the relevance level between the INQF-based curriculum established by Accounting Diploma 
Program of FE UNY and the 2013 IAI-KAPD version curriculum. Questionnaires were distributed to five lecturers of Accounting Diploma Program of AAYKPN, six lecturers of Accounting Diploma Program of UGM, and five lecturers of Accounting Diploma Program of UII to assess the relevance level between the INQF-based curriculum established by Accounting Diploma Program of FE UNY and the 2013 IAI-KAPD version curriculum. The scale used in this questionnaire instrument was the Likert scale with the respondent's choice category (Very Relevant $=4$, Relevant $=3$, Irrelevant $=2$, and Very Irrelevant $=1$ ). In the questionnaire, there were three sides of the column. The left side of the column was the INQF-based curriculum established by Accounting Diploma Program of FE UNY. The middle side column was the Likert scale scoring column. The right side column was the 2013 IAI-KAPD version curriculum.

\section{E. Data Validity}

The data validity was done by triangulation method. Researchers collect data that simultaneously test the data credibility, namely by testing the credibility of data with various techniques of data collection and diverse data sources.

\section{F. Instrument Validity and Reliability}

The validity of the instrument content was carried out by performing validation test or the appraisal from the expert. The experts were an expert in instrument construction (a Lecturer of Research and Evaluation of Education) and two experts in the material content of the instrument (Lecturer of Accounting of FE UNY). The validity was done with the formula developed by Aiken $(1985)^{16}$. The quality index of the validity of the questionnaires and interview guidance was $\geq 0.7$, therefore, the whole items had a good quality content (Sireci \& Geisinger, 1995, pp. 246-247) ${ }^{17}$. The reliability of the instruments in this study was determined using the intraclass correlation coefficient (ICC) (Shrout \& Fleiss, 1979) ${ }^{18}$. The result of ICC estimation on the reliability of instrument in this study indicated the single measures of 0.457 , hence it could be categorized into moderate reliability (Fleiss, 1999) ${ }^{19}$.

\section{G. Data Analysis Technique}

The validity of the instrument content was carried out by performing validation test or the appraisal from the expert. The experts were an expert in instrument construction (a Lecturer of Research and Evaluation of Education) and two experts in the material content of the instrument (Lecturer of Accounting of FE UNY). The validity was done with the formula developed by Aiken $(1985)^{16}$. The quality index of the validity of the questionnaires and interview guidance was $\geq 0.7$, therefore, the whole items had a good quality content (Sireci \& Geisinger,
1995, pp. 246-247) ${ }^{17}$. The reliability of the instruments in this study was determined using the intraclass correlation coefficient (ICC) (Shrout \& Fleiss, 1979) ${ }^{18}$. The result of ICC estimation on the reliability of instrument in this study indicated the single measures of 0.457 , hence it could be categorized into moderate reliability (Fleiss, 1999) ${ }^{19}$.

\section{Data Analysis Technique}

The procedure of data analysis for interviews with three lecturers of Accounting Diploma Program of FE UNY referred to Miles and Huberman (1984; 1994) (Denzin \& Lincoln, 2009, p.592) ${ }^{20}$. It consisted of three interrelated sub-processes, i.e., data reduction, data analysis, and conclusion. The relevance test of the INQF-based curriculum of Accounting Diploma Program of FE UNY was done through descriptive statistical analysis. The results of the percentage quantitative analysis were used to complement the qualitative results. The formula of percentage descriptive analysis (Sugiyono, 2014, p.138) ${ }^{21}$ is as follows:

$$
\mathrm{DP}=\frac{\text { Empirical score }}{\text { Ideal score }} \times 100 \%
$$

Where: DP $=$ Descriptive percentage (\%); Empirical score $=$ the obtained score; Ideal score $($ criterium $)=$ Ideal score for each item.

Therefore,

$$
\begin{aligned}
& \mathrm{DP}=\text { Descriptive percentage }(\%) \\
& \text { Empirical score }=(8+54+66+11)=139 \\
& \text { Ideal score }(\text { criterium })=((4 \times 16) \times 4)=
\end{aligned}
$$$$
256
$$

Percentage calculation:

$$
\mathrm{DP}=\frac{139}{256} \times 100 \%=54.29 \%
$$

$54.29 \%$ showed the relevance level between the INQF-based curriculum established by Accounting Diploma Program of FE UNY and the IAI-KAPD version curriculum (further explanation was in the section of the relevance level of the courses on this paper).

\section{RESULTS AND DISCUSSION}

\section{A. The Process of Curriculum Development of Accounting Diploma Program of FE UNY based on the $5^{\text {th }}$ Level of INQF}

The Process of the Development of Learning Outcomes of Accounting Diploma Program of FE UNY based on the 5th Level of INQF

The learning outcomes of a study program or the profile of study program graduates is a description of the roles and functions of the graduates of the study program after entering the working world or the real community. Based on the observation, the development of specific description and learning outcomes was performed by the Head of Accounting Diploma Program of FE UNY. In this process, the INQF issued by the Directorate General of Higher 
Education (Ditjen Dikti) became the reference by considering the vision and mission of the university and faculty as well as the characteristics of study program and university, especially the distinguished character of Universitas Negeri Yogyakarta.

Ideally, the development of learning outcomes is made based on the results of a tracer study on the alumni, stakeholder need assessment, scientific vision and SWOT analysis from study program and university (Ditjen Dikti, 2012, p.33) ${ }^{22}$. Meanwhile, the Head of Accounting Diploma Program of FE UNY emphasized the scientific vision approach (university values, university policy, and study program policy) as well as the stakeholder need assessment in preparing the learning outcomes in mid 2013. The SWOT analysis was not performed while the tracer study of alumni was conducted in the end of 2015. To promote the improvement in the process of learning outcomes preparation, SWOT analysis of program curriculum shall be aligned with the results of tracer study on the alumni.

\section{The Process of Graduates Learning Outcomes Preparation based on the $5^{\text {th }}$ Level of INQF}

The process of the determination of graduates learning outcomes was initiated by the authority given by the Head of Accounting Diploma Program of FE UNY to the respective subject lecturer. It is also confirmed by the interview with the Head of Accounting Diploma Program of FE UNY, who stated "the learning outcomes of a subject are assigned to the respective lecturer as mentioned in the Semester Learning Plans." Nevertheless, there are different interpretations as perceived by the Head of Accounting Diploma Program as the achievement of subject learning outcomes with the definition of graduates learning outcomes referred in this study.

The Directorate General of Higher Education (2012, p.38) explicates the three types of competence, namely: (1). the main competence as the characteristic of a study program, (2). supporting competency, and (3). other competencies, as added competencies provided by the respective study program as the characteristics of the graduates. The preparation of graduates learning outcomes is ideally conducted by the curriculum development team that evaluate the elements of the graduates or learning outcomes that have been defined in the initial drafting process, the INQF descriptor, and the standard of the National Professional Certification Agency (Badan Nasional Sertifikasi Profesi/ BNSP) or the latest is the National Standard of Higher Education (SN-DIKTI) (Ditjen Dikti, 2012, p.34).

To support the improvement of INQF-based curriculum of Accounting Diploma Program, the head of this program should form a curriculum development team to assist the curriculum and to conduct curriculum development analysis. In addition, to establish and strengthen the achievement of graduate learning or graduate learning outcomes, the discussion that involves all lecturers of Accounting Diploma Program of FE UNY is required.

Based on the findings on graduates learning outcomes devised by the lecturers of this program, most of them merely "copy and paste" the description of the course. Therefore, a discussion to facilitate the lecturers during the preparation of graduates learning outcomes is important. Learning outcomes of graduates in each subject of the study program should contain elements of attitudes, knowledge, general skills, and special skills as stated in SN-DIKTI (Ditjen Dikti, 2015, p.21) ${ }^{23}$.

The implementation of the $5^{\text {th }}$ level of INQF affects the graduates of diploma program since they will be unable to continue S-1 through the matriculation process by 2018. Basically, they have to follow the lecture from the beginning of $\mathrm{S}-1$ subject if they want to continue their studies. To attract the student interest in Accounting Diploma Program of FE UNY, it offers the opportunity for students with excellent achievement to continue their study to S-1 Accounting/Accounting Education (Extension Program). Therefore, in line with the implementation of the $5^{\text {th }}$ level of INQF, the Accounting Diploma Program of FE UNY should seek for an alternative to attract the student interest by highlighting the excellences of this program.

The interviews with the Head of Accounting Diploma Program of FE UNY disclosed that "the characteristic as the hallmark of this study program is its focus on entrepreneurship and Micro Small and Medium Enterprises (SMEs)." In accordance with this, it is important for this study program to devise a business and technology incubator program. Some of the biggest obstacles to business incubator development are the lack of entrepreneurial spirit, the start-up entrepreneurship financing issues and the business incubator network (Aernoudt, 2004) ${ }^{24}$. The establishment of entrepreneurship spirit in students can be done through seminars or workshops, programs or activities outside the curriculum that support the growth, development, and application of student entrepreneurial spirit. In addition, entrepreneurship seminars and workshops will also provide the students' insight to build a network with entrepreneurs.

The business and technology incubator program commenced by the Accounting Diploma Study of FE UNY will support its partnership with various SMEs. Recently, the business and technology incubatororiented programs have become a worldwide phenomenon (Tamasy, 2007) ${ }^{25}$. Collaboration with SMEs should be intensified particularly to promote mutual assistance in product and technology development, including in Accounting \& 
Bookkeeping Technology. It is also expected that the partner SMEs will become the users of the graduates of this study program. In addition, the students will have experiences and insights in implementing the knowledge gained in the lecture process through SMEs.

In the subjects focusing on SMEs, the students learn several materials, such as SMEs accounting and SMEs management as well as international accounting standard for SMEs and its applied management at ASEAN and global level. The goal of the $5^{\text {th }}$ level of INQF is to prepare professional and certified intermediate experts at national and international level. If those materials are solely emphasized on the practice in Indonesia, it is highly possible if the graduates of Accounting Diploma Program of FE UNY will have relative low competitiveness at global employment market.

The process of Curriculum Development for Accounting Diploma Program of FE UNY based on the $5^{\text {th }}$ Level of INQF

Based on the findings obtained from the interview, the process of curriculum development for the Accounting Diploma Program of based on the $5^{\text {th }}$ level of INQF was the results of scientific vision analysis carried out by the Head of this study program. In addition, the produced curriculum was discussed with the heads of other program studies and the Head of the Department of Accounting Education. Subsequently, the stakeholder need assessment was conducted in a meeting participated by the management of the study program and stakeholders and users in mid 2013 at Ros In hotel, Yogyakarta. In 2014, the implementation of INQF-based curriculum of Accounting Diploma Program of FE UNY even it had not been officially legalized.

The development of the initial draft was done independently by the Head of Accounting Diploma Program of FE UNY who asserted there was an absence of establishment or involvement of special curriculum development team as well as all lecturers in the preparation process. Based on the guideline issued by the Directorate General of Higher Education (2012, p.34), ideally there shall be a curriculum development team in the process of the determination of the graduates profile, the achievement or learning outcomes, and the concept of subjects and the credits. The participation of all lecturers is imperative, particularly in the selection process of study materials (comprehensive level, mastery level, and expected ability level) and the process of arranging the concept of integrated courses. Therefore, the Accounting Diploma Program of FE UNY in developing and preparing the curriculum needs to establish a curriculum development team and to involve lecturers as a whole in the selection process of study materials and the development of integrated courses.

The Inhibiting Factors in the Process of Curriculum Development for Accounting Diploma Program of FE $U N Y$

Several inhibiting factors were identified. Firstly, the number of extra courses, both from the university and respective faculty. The existence of these courses leads to the complexity in the distribution of the credit of each course. To address the issue about numerous extra courses, it is required to evaluate the relevance of the purpose of study program and the extra courses.

Secondly, the lack of time management or time allocation among the management of the Accounting Diploma Program of FE UNY in the development of INQF-based competency standards and curriculum. Thirdly, the personal factor in which the Head of the Accounting Diploma Program often misplaced the revised file. The two obstacles can be solved with the establishment of a curriculum development team to assist the head of the program and to evaluate and develop INQF-based curriculum. This curriculum development team will be in charge to back up of curriculum and revision data storage.

Fourthly, the lecturers had some difficulties in formulating the graduates learning outcomes that contain the character values. Fifthly, The difficulty in assessment per competence or evaluation of learning. Solutions to address these two barriers can be done with a discussion forum that involves all lecturers of this study program on the preparation of graduates learning outcomes, learning strategies, and learning evaluation in accordance with the $5^{\text {th }}$ level of INQF. In the forum, the experts from Directorate General of Higher Education, IAI-KAPD, and the educational assessment and evaluation can be invited. The forum is expected to provide convenience for the lecturers to intensely implement INQF-based curriculum for Accounting Diploma Program of FE UNY.

Based on the interviews with two lecturers of the program, the obstacles in learning, particularly related with the availability of library and laboratory facilities, were revealed. Solutions to overcome the limitations of libraries are by temporarily inviting the students and lecturers to take advantage of the onlinebased national library facilities.

Furthermore, the Accounting Diploma Program of FE UNY has to initiate collaboration with government agencies, SMEs, bank, and other institutions for the procurement of laboratory infrastructure facilities, such as taxation laboratory, mini bank, joint production business units, and others. The formation of alumni network or alumni forum is also required. Clark $(2001)^{26}$ suggested there are three alternative sources of fund to develop university programs, namely: (1) Government 
sources, which include funding from ministries or other agencies that have similar level with government as the main sponsors as well as local governments; (2) Organized private sources, including large to small industries, professional or civic associations, and social foundations; (3) general university revenues, such as university business units in the areas of services, products, alumni fund pools, and royalty from intellectual property patent products of the university. Sources of funds can be accessed and allocated for the development of laboratories and libraries and its facilities that support the implementation of teaching and learning activities.

\section{Supporting Factors in the Process of Curriculum Development for Accounting Diploma Program}

There are several supporting factors in this process. Firstly, there is policy and guidance from university or faculty management that support the implementation of INQF. To maintain and enhance the role of this first supporting factor, it is necessary to establish an evaluation team to assess the implementation of INQF, both at university and faculty. In addition, the university and faculty should conduct socialization and workshops on learning strategies and learning evaluation based on the INQFbased curriculum to all lecturers in UNY.

Secondly, the recognition of management of the program concerning with the importance of curriculum adjustment to the needs of the graduate users. The Head of Accounting Diploma Program recognizes the importance of curriculum suitability to the needs of the graduate users. To improve and facilitate the adjustment of the curriculum with the needs of the graduate users, it is necessary to establish a committee or board of graduate user. The committee or board contains the representatives of stakeholders, associations, users and alumni who may be invited at any time to assist in curriculum synchronization and curriculum evaluation.

Thirdly, the availability of guideline of INQFbased curriculum development published by the Directorate General of Higher Education (Ditjen Dikti). The availability of this guideline is very useful for the curriculum development. In addition to the guideline, the Ditjen Dikti shall also issue minimum course standards for each study program as a reference of the quality of Higher Education in Indonesia

\section{B. The Relevance between the Courses of Accounting Diploma Program of FE UNY and The $5^{\text {th }}$ Level of INQF \\ The Relevance Level of the Courses}

The assessment of courses conducted by the subjects through questionnaires indicated that the relevance level between the courses of Accounting Diploma Program of FE UNY and the courses of the $5^{\text {th }}$ level of INQF proposed by IAI-KAPD was $54.29 \%$. This level was the result of contribution from the number 1 and 2 courses in the 2014 curriculum book page 27-28 (FE UNY, 2014) ${ }^{27}$, which has been declared relevant with the $5^{\text {th }}$ level of IAI-KAPD. Meanwhile, the $45.71 \%$ irrelevance percentage was generated from the number 3 and 4 courses as mentioned in the 2014 curriculum book page 28 (FE UNY, 2014).

In the third descriptor, the supplementary courses shall encourage the ability to manage the working group and to prepare a comprehensive written report. Courses listed by IAI-KAPD to represent this descriptor are Human Resource Management, Bahasa Indonesia, Business Statistics, Business Communication, and Professional and Business Ethics. Meanwhile, the subjects listed in the 2014 curriculum of the Accounting Diploma Program of FE UNY that represent this descriptor are Introduction to Accounting $1 \& 2$, Intermediate Financial Accounting $1 \& 2$, Advanced Financial Accounting, and so on.

Furthermore, course that represents the $4^{\text {th }}$ descriptor listed by IAI-KAPD is Human Resource Management. Meanwhile, this course is not listed in the 2014 INQF-based curriculum of Accounting Diploma Program of FE UNY. Therefore, revision of this curriculum should be made, particularly to adjust it with the generic description of Presidential Regulation No. 8 of 2012. Additionally, it is important to evaluate the supporting courses based on this generic description.

\section{The Results of the Suitability Analysis between the Courses}

The results of the distribution of the list of courses in the 2014 INQF-based curriculum of Accounting Diploma Program of FE UNY 2014 and the $5^{\text {th }}$ level of INQF published by IAI-KAPD showed there are some points. First, the absence of Business and Professional Ethic, Business Communication, and Human Resource Management in the curriculum of Accounting Diploma Program, even though these courses support the achievement of the third and fourth descriptors. Second, the subject of Accounting Management becomes an elective course in the curriculum of Accounting Diploma Program, which is different from the curriculum established by IAIKAPD.

Third, Spreadsheet application has not been included on the 2014 INQF-based curriculum of FE UNY. In the $5^{\text {th }}$ level of INQF-based curriculum based on IAI-KAPD, there are three courses of practical computer application, namely: Spreadsheet application, Practical Data Processing Application, and Practical Accounting Application. In fact, Computer Applications and Accounting Computer are listed in the 2014 INQF-based curriculum of 
Accounting Diploma Program, but the researchers perceive these courses merely represent Practical Spreadsheet Application and Practical Accounting Applications, while Practical Applications Data Processing has not been clearly stated.

Fourth, the percentage of comparison between the theory courses with the overall practice of the 2014 INQF-based curriculum of Accounting Diploma Program of FE UNY was 42.02\%: $57.98 \%$, in which it ideally $40 \%$ : $60 \%$. Puspita $(2015)^{28}$ suggested some important capabilities that should be possessed by the graduates in accounting in facing the global competition, namely English proficiency, communication skills, management skills, financial information systems, business software applications, and legal and tax knowledge.

Another perspective was propounded by Salem $(2013, \text { p.66) })^{29}$ in an attempt to adapt a curriculum to global competition where "practitioners should impress upon educators the need to teach classes that are relevant to today's business world, including technology, globalization, and ethics." Therefore, the global competition that emphasizes on the mastery of global competence, technology, and ethics must be a task for the management of Accounting Diploma Program of FE UNY in devising a curriculum that can accommodate all the advancement of science and technology and the suitability with the needs of the global community.

\section{CONCLUSION}

Based on the results and discussion of the description of data as presented in the previous chapters, it can be concluded that: First, the Head of the Accounting Diploma Program of Faculty of Economics UNY, emphasizes the scientific vision approach (the university values, the university policy and the study program policy) in the development of INQF-based learning outcomes and program subjects. Furthermore, the results were discussed to the heads of other study programs and the Head of Accounting Education Department. The process of development was followed by the stakeholder need assessment in mid 2013. SWOT analysis was not conducted, while the tracer study of alumni was initiated in the end of 2015 whereas the curriculum has been prevailed since 2014.

Furthermore, the Head of Accounting Diploma Program of FE UNY gives the authority to the respective lecturer to perform the determination of the graduates learning outcomes. The preparation of graduates learning outcomes is ideally performed by a curriculum development team that involves the elements of graduates profile or learning outcomes that have been defined in the initial drafting process, INQF descriptor, and standard of the National Professional Certification Agency $(B N S P)$ or the National Standard of Higher Education ( $S N-D I K T I)$.
Nevertheless, there are several inhibiting factors in the development of the curriculum of Accounting Diploma Program of FE UNY. They include: the various extra subjects from university and faculty, the insufficient time management or time allocation in the INQF-based curriculum development, the missing revised file, the difficulty in the preparation of graduates learning outcomes particularly those which contain the character values, the complexity in the assessment of each competency or learning evaluation, and the lack of library and laboratory facilities. Meanwhile, there are several supporting factors, including: the policy and guidance established by university and faculty management to support the implementation of INQF, the recognition of the Head of Accounting Diploma Program of FE UNY on the required curriculum adjustment to the needs of the graduate users, and the availability of the guideline of INQF-based curriculum development published by the Directorate General of Higher Education, Ministry of National Education, Indonesia.

Furthermore, the relevance level of the courses in the curriculum of Accounting Diploma Program with the $5^{\text {th }}$ level of INQF published by IAI-KAPD was $54.29 \%$. The suitability analysis showed the ratio between the theory courses and the overall practice on INQF-based curriculum is still equal to $42.02 \%$ : $57.98 \%$, while the ideal is $40 \%$ : $60 \%$. It is due to the absence of several courses, including Business and Professional Ethics, Business Communication, and Human Resource Management on the INQF-based curriculum of Accounting Diploma Program of FE UNY. Management Accounting becomes an elective course, while Practical Data Processing Applications has not been included on the 2014 INQF-based curriculum of Accounting Diploma Program of FE UNY.

\section{ACKNOWLEDGMENT}

I'm enormously grateful to my supervisor, Mrs. Nahiyah Jaidi Faraz for warm support, inspiration and thoughtful guidance. This research was supported by Mrs. Amanita Novi Yushita, Head of Accounting Diploma Faculty of Economics Universitas Negeri Yogyakarta, Indonesia. I'm especially grateful to Mr. Sukirno, Vice Dean I Faculty of Economics Universitas Negeri Yogyakarta for constructive criticism and advice to my research. Any errors are my own and should not tarnish the reputations of these esteemed persons.

\section{REFERENCES}

[1] Priestley, M. (2002). Global Discourses and National Reconstruction: the Impact of Globalization on Curriculum Policy. The Curriculum Journal, 13 (1): 121-138.

[2] Parker, W.C., Ninomiya, A.,\& Cogan, J. (1999). Educating World Citizens: Toward Multinational Curriculum Development. American Educational Research Journal, 36 (2): 117-145. 
[3] Wijeyaratne, M.J.S. (2012). Srilanka Qualifications Framework (Colombo, Sri Lanka: The World Bank Funded HETC Project of the Ministry of Higher Education).

[4] Presiden RI. (2012). Peraturan Presiden RI Nomor 8, Tahun 2012 tentang Kerangka Kualifikasi Nasional Indonesia.

[5] UNDP. (2016). Human Development Report 2016 (New York, U.S.: United Nations Development Programme).

[6] Lanvin, B. \& Evans, P. (2016). The Global Talent Competitiveness Index 2015-2016 (Singapore: INSEAD \& HCLI (Human Capital Leadership Institute)).

[7] Lanvin, B. \& Evans, P. (2017). The Global Talent Competitiveness Index 2017 (Singapore: INSEAD \& HCLI (Human Capital Leadership Institute)).

[8] Soenarto, Kartowagiran, B., dan Jaedun, A. (2013). Model Evaluasi Penjaminan Mutu Sekolah. Laporan Penelitian Hibah Pascasarjana UNY, (29 November 2013).

[9] Sambada, D. \& Zuchdi. (2002). Evaluasi Pelaksanaan Program Penyetaraan D-II PGSD FKIP Universitas Terbuka Surabaya. Jurnal Penelitian dan Evaluasi Pendidikan, 4 (5): 60-71.

[10] Lukitawati, R. (2004). Manajemen Proses Pendidikan Program Diploma IV Bidan Pendidik Fakultas Kedokteran Universitas Gadjah Mada Yogyakarta. Jurnal Penelitian dan Evaluasi Pendidikan, 6 (1): 1-10.

[11] Latifah, D. (2012). Evaluasi Mata Kuliah Piano untuk Menghasilkan Guru Musik di Sekolah. Jurnal Penelitian dan Evaluasi Pendidikan, 16 (2): 457-473.

[12] Supriyadi, E. (2012). Kajian Kurikulum Jurusan Pendidikan Teknik Elektro Fakultas Teknik Universitas Negeri Yogyakarta Mengacu pada Kerangka Kualifikasi Nasional Indonesia. Jurnal Pendidikan Teknologi dan Kejuruan, 21 (2), 156-166.

[13] IPB. (2012). Penjabaran KKNI Jenjang Kualifikasi V ke dalam Learning Outcomes dan Kurikulum Program Keahlian Akuntansi.
http://kms.ipb.ac.id/.../LO\%20dan\%20Kurikulum \%20D3_N, on (13 October 2014).

[14] Jati, B.P. (2013). Rekonstruksi Kurikulum Berbasis KKNI pada Perguruan Tinggi Vokasi Akuntansi untuk Menjawab Peluang dan Tantangan Pasca UU 12/2012 dan Perpres 8/2012. Makalah, Simposium Nasional Akuntansi XVI, IAIKAPD, (25 September 2013). Manado, Indonesia: IAIKAPD.

[15] Isti. (2013). Hasil Akreditasi Jurusan di Fakultas Ekonomi Universitas Negeri Yogyakarta. Retrived from: http://fe.uny.ac.id/berita/hasil-akreditasi-jurusan-di-fakultasekonomi-universitas-negeri-yogyakarta, on (31 August 2014).

[16] Aiken, L.R. (1985). Three Coefficients for Analyzing the Reliability and Validity of Ratings. Educational and Psychological Measurement, 45: 131-142.

[17] Sireci, S. G. \& Geisinger, K. F. (1995). Using Subject-Matter Experts to Assess Content Representation: an MDS Analysis. Applied Psychological Measurement, 19 (3): 241-255.

[18] Shrout, P.E. \& Fleiss, J.L. (1979). Intra Class Correlations: Uses in Assessing Rater Reliability. Psychological Bulletin, 86 (2): 420-428.

[19] Fleiss, J. L. (1999). The Design and Analysis of Clinical Experiments (New York, U.S: John Wiley \& Sons Inc).

[20] Denzin, N.K. \& Lincoln, Y.S. (2009). Handbook of Qualitative Research (California, U.S: Sage Publications).

[21] Sugiyono. (2014). Metode Penelitian Kombinasi (Mixed Methods). (Bandung, Indonesia: ALFABETA).

[22] Ditjen Dikti. (2012). Panduan Pengembangan dan Penyusunan Kurikulum Perguruan Tinggi (KPT) Pendekatan Kurikulum Berbasis Kompetensi (KBK) dan Pendidikan Berbasis Capaian (PBC) (Jakarta, Indonesia: Ditjen Dikti).

[23] Ditjen Dikti. (2015). Buku Kurikulum Pendidikan Tinggi Pengembangan Kurikulum Pendidikan Tinggi Mengacu KKNI dan SN DIKTI (Jakarta, Indonesia: Direktorat Pembelajaran dan Kemahasiswaan).

[24] Aernoudt, R. (2004). Incubators: Tool for Entrepreneurship? Small Business Economics, 23 (2): 127-135.

[25] Tamasy, C. (2007). Rethinking Technology-Oriented Business Incubators: Developing a Robust Policy Instrument For Entrepreneurship, Innovation, And Regional Development? Growth and Change, 38 (3): 460-473.

[26] Clark, B. (2001). The Entrepreneurial University: New Foundations for Collegiality, Autonomy, and Achievement. Higher Education Management, 13 (2): 9-24.

[27] FE UNY. (2014). Kurikulum 2014 Program Studi Akuntansi Diploma III Berbasis Kerangka Kualifikasi Nasional Indonesia (KKNI). (Yogyakarta, Indonesia: UNY).

[28] Puspita N.W.P. (2015). Peranan Kurikulum dalam Peningkatan Kompetensi Lulusan Akuntansi di Era Masyarakat Ekonomi ASEAN. Prosiding Seminar Nasional, (9 Mei 2015): 481-489. (Yogyakarta, Indonesia: UNY).

[29] Salem, M.S.M. (2013). The Future of Accounting as a Subject in a Business School: A Literature Review. The Journal of Human Resource and Adult Learning, 9 (2): 62-69. 